\title{
The Direction of Physical and Health Education in 21 st century in Malaysia
}

\author{
1Shahrulfadly Rustam and ${ }^{1}$ Mohar Kassim \\ ${ }^{1}$ Centre for Coaching Science, National Defence University of Malaysia, Sungai Besi Camp, 57000 Kuala Lumpur, Malaysia.
}

Correspondence Author: Shahrulfadly Rustam, Centre for Coaching Science, National Defence University of Malaysia, Sungai Besi Camp, 57000 Kuala Lumpur, Malaysia.

Received date: 12 January 2018, Accepted date: 10 March 2018, Online date: 20 March 2018

Copyright: (C) 2018 Shahrulfadly Rustam and Mohar Kassim. This is an open-access article distributed under the terms of the Creative Commons Attribution License, which permits unrestricted use, distribution, and reproduction in any medium, provided the original author and source are credited.

\begin{abstract}
Twenty-first century formal and informal learning environments found in schools and in the community must be crafted to inform, inspire, and transform individuals to enhance their lives, work, and play. The world is increasingly interconnected and learning environment that will require a more global perspective, in terms of culture and context related. Technology will provide a way to spread information from one part of the world to another world. The impact of globalization in education affect the learning environment of the twenty-first century with the communication of ideas, concepts and ideas in society. This article explains the problems that occurred in the Physical and Health Education curriculum (PHE) on the twenty-first century and peeling the importance and the challenges faced in this century. It also discusses the extent to which the direction of the Physical and Health Education can empathize with the National Education Philosophy in other words to elevate it. But to uphold the desire, various obstacles and problems in the Physical and Health Education curriculum should be acted upon. Among them is the attitude of school administrators towards Physical and Health Education and the attitude of the students themselves involved in Physical and Health Education activity in schools. It is hoped this article can give input to the reader or researcher in searching for solutions in Physical and Health Education curriculum so that it is parallel to the goal of the National Education Philosophy.
\end{abstract}

Key words: Physical and Health Education; problem; twenty-first century; national education philosophy

\section{INTRODUCTION}

The education system in our country is focuses on basic education to produce a good, comprehensive and integrated in terms of physical, emotional, intellectual and spiritual character. It is clear based on what is written in the National Education Philosophy. Elements of attitude, morals and values is an important element in ensuring that the National Education Philosophy is reached. This is clearly contained in the National Education Philosophy:

"Education in Malaysia is an ongoing effort towards further developing the potential of individuals in a holistic and integrated to create a balanced and harmonious intellectually, spiritually, emotionally and physically based on trust and obedience to God. This effort is to produce Malaysian citizens who are

knowledgeable and competent, honourable, responsible and capable of achieving well-being and contribute to the betterment of society and the state" (Curriculum Development Centre [1]).

One of the important aspects in the National Education Philosophy is the formation of human morality. Hence, the importance of moral values among people is very important, because the internalized values that will determine the kind of man you want. Therefore, education and implementation of value cannot be separated. Can be said that education would not be complete without the application of means and values [2]. It is these values that shape the way an individual could behave, think and act so as to shape culture or norms of society.

The emphasis on the question of values in the education system in Malaysia is given attention. The serious attention began with the implementation of the Curriculum for Primary Schools (KSSR) in 1983 and the Integrated Curriculum for Secondary Schools (KBSM) in 1989 that encourages teachers to carry out the implementation of the cross-curricular approach (Curriculum Development Centre, 1988). [3]. Implementation of values is not limited to the Islamic Studies, Moral and Civics and Citizenship Education, but applied through all the subjects taught in schools, through the daily activities and extra-curricular activities [4-5].

This clearly proves that the implementation of moral values in teaching is an important agenda in the national education system. The implementation aspects of values in the 'KBSM' is important, especially to provide students with a strong endurance. Students are educated through the school system must be able to face the challenges of current and future challenges. This ambition will be achieved if they live up to the values that guarantee the personal formation and personality intact, thick and solid [6].

\section{THEORETICAL OVERVIEW}

The challenges curriculum in Physical and health education:

At the same time obesity and overweight is increasing, but the Physical and Health Education program schools is decreasing. According Edginton [7] explains that, the amount of time dedicated to physical education have slipped into school curricular around the world. Hardman and Marshall [8-9] states that the Physical and Health Education program are being deemphasized. Perhaps a greater emphasis placed on accountability and high-stakes testing has resulted in a reduction in coursework related to Physical and Health Education [10]. Instead, the physical education curriculum might lack in terms of charging and mostly offered in a way that is irrelevant and failed to inspire and motivate young people.

School administrators evidently have not linked the increase in obesity and overweight to the diminishing of physical education programs [10]. Physical educators have failed to ensure that the linkage between their efforts in the classroom and the health and cognitive development of their students is understood. The responsibility rests directly on the shoulders of physical educators to ensure that the importance of their subject matter is understood and embraced as a part of Advances in Natural and Applied Sciences 
their schools' overall curriculum. Today, more than ever, the physical education curriculum needs to be linked to the overall well-being of children and youth as they matriculate through the curriculum. As has been noted, lessons learned at an early age carry into adult life.

Furthermore, the importance of physical activity as a way to create greater attention in the classroom is not recognized. Opportunity for schools to provide Brain Breaks, which stimulates students and reenergize their efforts, largely been ignored in the curriculum as a whole. Brain Breaks stimulate the potential of individuals to access and process the new information [11-12].

Edginton et al, [13] stated that the challenge will require a more personal or individual students and teachers. In the future, the ability to think critically, solve problems, innovate, operate with agility and adaptability, and to communicate effectively and work efficiency with technology, will create a single dominance in the educational environment. The learning environment of the twenty-first century is included; (1) Increased capacity and efficiency to promote learning for students is relatively large amounts at one time; (2) Increased effectiveness by promoting deep learning approach and relationship to the real environment; (3) Access by removing barriers; (4) Generation of competitive thinking with a wide range of facilities to students; (5) Promotion of resource-based emphasis provides a more student-centred process; and (6) Enable students and teachers have a close relationship in all situations.

Case Study: Physical and health education in $21^{\text {st }}$ century:

Physical and Health education programs around the world are challenged to provide learning experiences that are meaningful and appropriate for children and adolescents. In the 21st century, learning strategy will be a different aspect, which require children and teenagers to acquire critical thinking and problem solving skills, to operate with agility and adaptability, analyze information effectively, communicate in various oral and written forms, reflecting the curiosity of the larger, imagination, and innovation in their thinking, and develop a healthy lifestyle and active [14-15]. Based on Kassim [30] observation, the school environmental constrains must be overcome by reviewing back at all the equipment and facilities in school before reframing the Physical and Health education curriculum.

In a changing world, a broader global perspective in the pedagogy of teaching Physical and Health Education is needed. It is clear that we can and should learn from each other through communities around the world. Cultural world that is increasingly global and communication technology enables outstanding professional practice in one part of the world to be reviewed and adopted in the appropriate state. Without question, knowledge of global international practices can assist in advancing Physical and Health education pedagogy worldwide.

We live in a world today are related to each other. Globalization has promoted a way to integrate ideas and concepts from around the world. Educational practices in one country, like other processes in business, government, or other places, can be shared in another context with adaptation to local culture. Edginton and Chin [16] notes that, we can think of as a program of best practices, processes and procedures and regularly produces superior results compared to other strategies. In part, Physical Education and Health at the global perspective and best practices were identified in the field of pedagogy of Physical and Health Education.

Several significant developments worldwide have contributed to the timeliness of this publication. First, conscientiousness of the interconnectedness of physical education and health educators is growing on a worldwide basis. Increasingly, technology provides opportunities to share information and to establish networks with our colleagues throughout the world. What constitutes best practice in one country may be adapted easily in a culturally relevant context in another country. Second, obesity and overweight are being acknowledged as a worldwide epidemic. More obese and overweight individuals live in the world than malnourished individuals, creating serious challenges to the health of individuals and to the health care system [17]. Third, the provision of physical education program as part of the school curriculum is decreasing globally $[8-9,18]$. At a time when the health and welfare of children and young people are challenged, resources and solutions to the concerns that are being eliminated from the basic school curriculum.

\section{The curriculum of physical education in Malaysia:}

Physical education is an important subject in the curriculum of formal education in the education system in Malaysia and is recognized as one of the most important activities to develop the habit of physical activity during adolescence [19]. Physical education is also designed to instill confidence, comply with regulations, improve skills and cultivate a spirit of cooperation among students. Physical education is a subject that aims to educate students to engage in sports activities, recreation, social and health care. In addition, students also have the skills to act in an emergency and can apply a healthy lifestyle. The goal of Physical Education is to encourage students to maintain a healthy lifestyle by engaging active in physical activity. According to Eleanor Ann et al., [20] Physical Education help to improve the ability of students through physical activity, social, emotional and cognitive development. This is consistent with the goal of Philosophy of Education in developing the students in terms of Physical, Emotional, Spiritual, Intellectual and Personality. There are many benefits to be gained by engaging in Physical Education activities such as to build confidence, socialize, work and others. This subject has been given a major role in the country's education system, to produce a healthy, strong and fit as well in addition to mastering the skills of sports and competition aspects when selected to participate in school sports teams.

The aim of Physical Education is designed to meet the needs of growth and development of the individual towards developing a vibrant, prosperous and productive community. Basically, Physical Education was established to build physical strength and health of the students through the core sports and a number of titles to keep fit. Physical Education is the only subjects that form the overarching learning because these subjects provide elements that can be used by all levels of students. It is a holistic and seeks to develop students from various aspects and can lead to the success of one group of students [21]. Physical education is a very important program to introduce students to the physical activity from childhood to adulthood. So Physical Education has been drafted by the Ministry of Education to achieve the National Education Philosophy and to meet the needs of growth and development of the individual towards developing a vibrant, prosperous and productive community.

This curriculum is divided into three learning outcomes, that's fitness, skills and sportsmanship. These three learning outcomes help to achieve the goals and objectives of Physical and Health Education. To form a high appreciation of Physical and Health Education, students need to understand and appreciate the knowledge, skills and experience of Physical and Health Education towards establishing a society that practices a healthy lifestyle. Physical and Health Education curriculum planned and promote an conducive environment to teaching and learning to enhance students' potential to the optimum.

The main objective of physical education curriculum through the Physical Education Syllabus, in 1999 is: to improve and maintain fitness based on health and motor activity, to master in fundamental movement skills and game according to their own pace, to do exercise and physical activity as a daily routine, to apply knowledge of health and safety while participating in various physical activities, to build character and self-discipline and to make wise decisions in life.

Physical and Health Education activities undertaken at school is an organized activity and capable of providing a good environment to help students appreciate the importance of fitness and health care. Therefore, teachers should always understand the ultimate goal of Physical and Health Education, which according to the Curriculum Development Centre (1999) [22], Physical and Health Education is aimed to helping students to become active through physical activity learning and fitness practices.

Based on the objectives of Physical and Health Education, which aims to achieve the level of fitness and sports skills. The objective can be achieved by focusing specifically on the relationship between the practice of health with physical fitness and motor skill. This method is seen as able to control the disease in daily life.

The objectives and goals of the National Education Philosophy which aims to produce human who are intellectually from the physical, spiritual, emotional, social and intellectual development through the Physical and Health Education curriculum and all these aspects are able to achieve. This is based on the need and inspiration that have been described in the Physical and Health Education Teacher's Guide [23]. 
MODELS OF PHYSICAL AND HEALTH EDUCATION OF $21^{\text {ST }}$ CENTURY

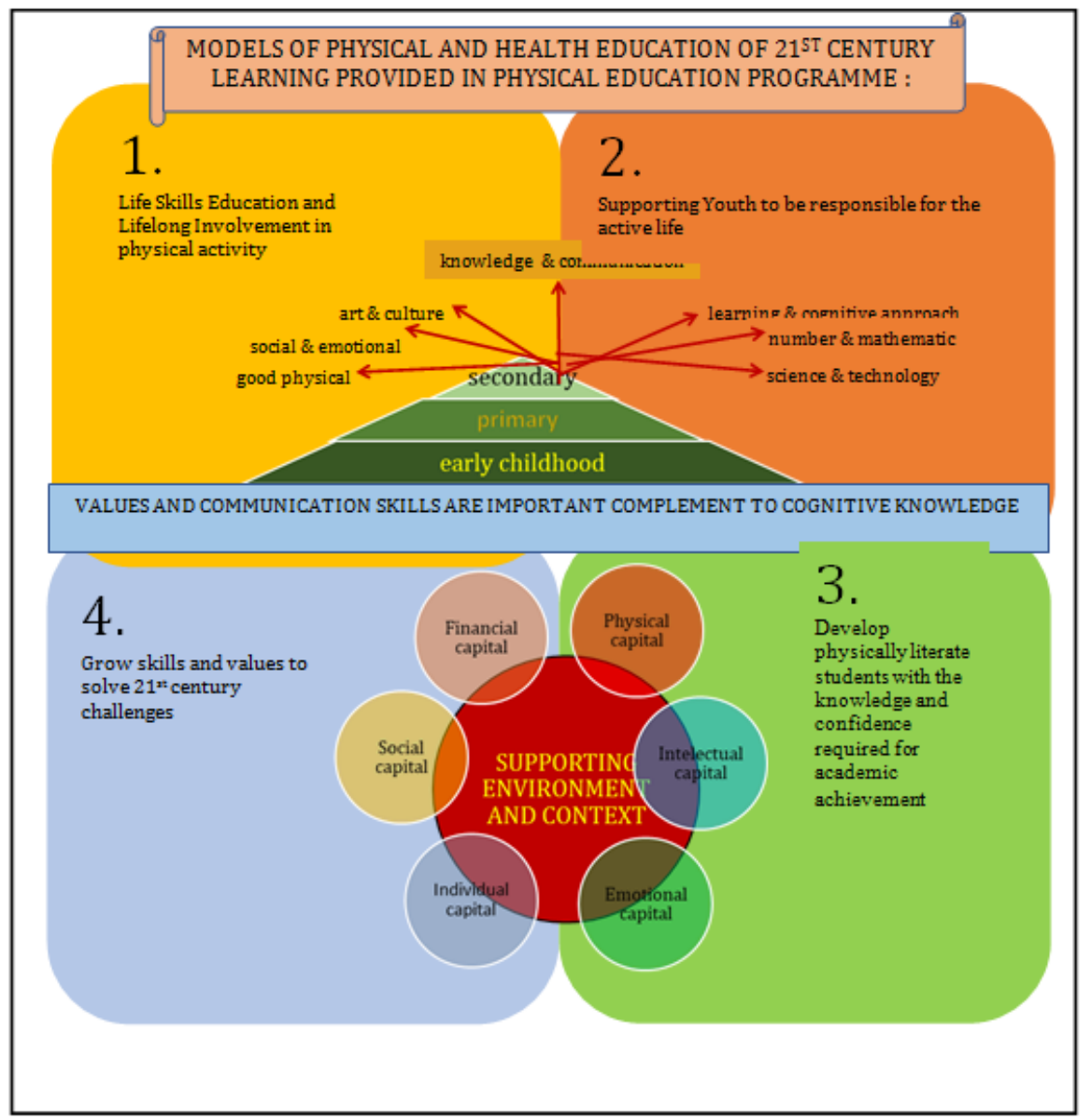

Source: Modified from the Ever Active Schools (2000) [24]. 21st Century PE Teachers Elementary.

Problems in the teaching and learning of physical and health education at Malaysia:

Physical education, especially in secondary schools are experiencing instability, which is less desirable among students [25-26]. Involvement of students in learning physical activity is still at low levels. This fact was confirmed by a survey conducted by the Research Institute of Youth Development, found the youth in this country are not active in leisure which they did not participate in any physical activity or activities of association or club, lack of exercise and lack of sport activity, and much loungers activities. Whereas in the study by Halijah and Omar (2008) [27], found 81 percent of students considered English subjects 'Very Important', 55 per cent of the Living Skills subject is considered 'important'. For subjects Physical education only 15 percent who said 'Very Important'.

Most students who study at the secondary level is less interested in physical activity by providing a variety of reasons. Some states that Physical Education has no academic value, their extra body grows, unhealthy, clothing left behind and others reason. There much reasons given by students for not following the activity. The issue of students not wearing sports clothing during Physical Education classes still persists until today [28]. In Haslindah et al [28] study, also found that $67.0 \%$ of teachers think that the majority of students do not want to wear sports clothes during physical education classes. This attitude has caused frustration among teachers who teach physical education. Hence this situation has caused of stress among teachers who teach Physical Education.

This may be due to Physical and Health Education curriculum consists of sport or Physical and Health Education are basically more concerned with sports. According to Armstrong (1990) [29], the concept of physical education and sport is different. An example is the physical education involves teaching and learning process, while sport just a recreational activity. Physical education usually run by teachers while the sporting operated by skilled trainers for specific sports. Physical education more of student-centred and self-development of students, but the sports is more oriented the specific sports and development of the sport. Physical and Health Education must achieve the objectives of the three aspects of the psychomotor, cognitive and affective. This contrasts with other academic subjects that only have cognitive and affective domain to achieve.

Physical education is a special subject of the initial establishment of the Ministry of Education. But in 1988, it was reorganized into a single curriculum subjects, namely Physical and Health Education. In 1999, Physical and Health Education curriculum is broken down into two subjects, namely, Physical Education and Health Education. Physical Education and Health Education is designed to meet the needs of growth and development of the individual in shaping the community vibrant, prosperous and productive, in addition to adopting a healthy lifestyle. Physical Education and Health education helps students become active and knowledgeable with the fertilization of skills, values and practices of fitness. Implementation of Physical Education and Health Education which includes aspects of health and fitness in schools give more challenge to administrators and teachers of Physical Education and Health Education.

The problem nowadays, although both of these subjects has been recognized, according to the Education Act 1996 (Professional Circular Nos. 25/1998), but the subjects of Physical Education and Health Education has long been marginalized in school unnoticed. Physical Education and Health Education lessons are considered incidental, and lack of monitoring of the school. It is probable that this situation is due to the Physical Education and Health Education no centralized examination or not assessed in national examinations and no record of student achievement. Physical Education instructional time is only used to play or with other words no teaching and learning are carried out in accordance with the syllabus specified. Furthermore, most of the teachers who taught Physical Education and Health Education not from the teacher who option in Physical Education and Health Education programme, but only as a supplement on the school timetable.

\section{CONCLUSION}

Life, work, and play in the 21 st century will bring many challenges and opportunities. It will be necessary to approach colleagues from around the world to develop and adopt strategies, methods, procedures, and a new program to address the emerging need. In many respects, the pedagogy of Physical and Health Education should be rethought and perhaps reinvented. 
Exploration of best practices in new and different models can be the starting point for reform of Physical and Health Education at the world level. Physical and Health Education is the core of the development of individual potential as envisioned in the mission of the Ministry of Education to build a quality education system and developing the potential for world-class individual and meet the aspirations of the country. National Education Philosophy also stressed the responsibility of the individual in order to produce Malaysian citizens who are balanced in terms of physical, emotional, spiritual, intellectual, moral as well as knowledgeable and competent, honorable, responsible and capable of achieving well-being and contribute to the harmony and prosperity family, community and country.

But what happens nowadays, Physical and health Education were ignored by the school administration. Most school administrators and some educators gave a negative perception of Physical and Health Education. This group considers that the Physical and Health Education is a subject for a play and only form of nonacademic curriculum. The Physical and Health Education is not taught properly, as discussed in the theory and caused the quality of teaching and learning of these subjects did not achieve its objectives. In fact, not only that, there is a group of school administrators who pursue prefixes in the form of remuneration of finance if the performance of academic subjects such as math, science, physics, chemistry, biology and English reach to high levels of performance and this causes the Physical and Health Education in disregard.

According Desma and Abdul Aziz [26] states that physical education, especially in secondary schools are experiencing instability, which is less desirable subjects among students. This can be seen with the involvement of students in physical education activities are still at a low level. Most students who study at the secondary level is less interested in physical activity by providing a variety of reasons such as states Physical Education has no academic value and unhealthy.

Teachers and school administrators must play a role in the success of the National Education Philosophy thus will uphold the aspirations of education who want to put a world-class education in Malaysia. Montel explains that the subject of Physical and Health Education is very important for being one of the mainstays in the aspirations of the National Education Philosophy which is in the core of physical activity and the aesthetic both synonymously of these aspects can be blended properly in good implemented. With the implementation of elements of the educational philosophy more clearly in the process of teaching and learning, then all the aspirations and intentions contained in the National Education Philosophy can be realized successfully to produce individuals who are knowledgeable and balanced in terms of spiritual, intellectual, emotional, physical and personality as outlined in the National Education Philosophy will become a reality.

\section{ACKNOWLEDGEMENTS}

I would like to convey my heartiest appreciation to the Centre of Coaching Science, and the Research and Innovation Division of the National Defence University of Malaysia for giving me the opportunity to conduct and publish the result of this research.

\section{REFERENCES}

[1] Pusat Perkembangan Kurikulum, 2005. Buku panduan pengajaran dan pembelajaran nilai merentas kurikulum KBSR I KBSM. Kuala Lumpur: Kementerian Pelajaran Malaysia.

[2] Wan Mohd. Zahid, M.D., 1994. Pengisian wawasan pendidikan. Kertas kerja yang dibentangkan dalam Seminar Pendidikan Nasional Peringkat Negeri Pulau Pinang, pada 18 September 1993, di Dewan Sri Pinang, Pulau Pinang.

[3] Curriculum Development Centre, 1988. Buku panduan pengajaran dan pembelajaran nilai merentas kurikulum KBSR I KBSM. Kuala Lumpur: Kementerian Pelajaran Malaysia.

[4] Nor Hashimah, H., 2000. Pemahaman guru terhadap penerapan nilai-nilai murni di dalam mata pelajaran Bahasa Melayu di sekolah rendah. Laporan penyelidikan Pusat Pengajian Ilmu Pendidikan Universiti Sains Malaysia.

[5] Rahimah, A., L.H. Chang, 1997. Pendidikan moral dan nilai adalah asas meningkatkan martabat profesion perguruan. Prosiding Konvensyen Kebangsaan Pendidikan Moral dan Nilai dalam Pembangunan manusia. Bangi : Fakulti Pendidikan, Universiti Kebangsaan Malaysia.

[6] Wan Mohd. Zahid, M.D., 1988. Ke arah pelaksanaan nilai-nilai murni di dalam KBSM: Falsafah Pendidikan Negara. Kertas kerja yang dibentangkan dalam Seminar Nilai-nilai Murni Merentas Kurikulum Dalam KBSM di Universiti Kebangsaan Malaysia, Bangi, Malaysia.

[7] Edginton, C.R., 2007. Has physical education failed? Asian Journal of Exercise \& Sports Science. 3(1): 1-7.

[8] Hardman, K. and J. Marshall, 2009. Second world-wide survey of school physical education: Final report. Berlin: International Council of Sport Science and Physical Education.

[9] Hardman, K. and J. Marshall, 2000. World-wide survey of the state and status of school physical education: The final report to the International Olympic Committee. Manchester: University of Manchester.Halijah, I.

[10] Edginton, C.R. and M.K. Chin, 2012. Promoting best practice. The Global Journal of Health and Physical Education Pedagogy, 1(4): i-ii.

[11] Davis, C.L., P.D. Tomporowski, J.E. McDowell, B.P. Austin, P.H. Miller, N.E. Yanasak and J.A. Naglieri, 2011. Exercise improves executive function and achievement and alters brain activation in overweight children: A randomized, controlled trial. Health Psychology, 30(1): 91-98.

[12] Hillman, C.H., K.I. Erickson and A.F. Kramer, 2008. Be smart, exercise your heart: Exercise effects on brain and cognition. Nature Reviews Neuroscience, 9(1): 58-65.

[13] Edginton, C.R., M.K. Chin, P. Geadelmann and I. Ahrabi-Fard, 2011. Global Forum for Physical Education Pedagogy 2010 (GoFPEP 2010): Health and physical education pedagogy in the $21^{\text {st }}$ century - A statement of consensus. International Journal of Physical Education, $48(2)$ : $33-41$.

[14] Gut, D.M., 2011. Integrating 21st century skills into the curriculum. In G. Wan \& D. M. Gut (Eds.), Bringing schools into the 21st century, 13 : $137-157$. Dordrecht: Springer Netherlands.

[15] Kay, K. and V. Greenhill, 2011. Twenty-first century students need 21st century skills. In G. Wan \& D. M. Gut (Eds.), Bringing schools into the 21st century pp: 41-65. Dordrecht: Springer Netherlands.

[16] Edginton, C.R., M.K. Chin and R. Naul, 2012. The Global Forum for Health and Physical Education Pedagogy: A new social movement. International Journal of Physical Education, 49(3): 31-39.

[17] Sanders, D., F.E. Baum, A. Benos and D. Legge, 2011. Revitalising primary healthcare requires an equitable global economic system - now more than ever. Journal of Epidemiology \& Community Health, 65(8): 661-665.

[18] Hardman, K., 2011. Global issues in the situation of physical education in schools. In K. Hardman \& K. Green (Eds.), Contemporary issues in physical education pp: 11-29. Maidenhead: Meyer \& Meyer Sport.

[19] Sallis, J.F., 1991. Self-report measures of children's physical activity. Journal of school health, 61(5): 215-219.

[20] Eleanor Ann, T.L.N., M. Munira, C.M. Chia, M.N. Gananathan, 2014. Kurikulum dan Pedagogi Pendidikan Jasmani. Kuala Lumpur: Oxford Fajar Sdn. Bhd.

[21] Colfer, G.R., 1986. Contemporary physical education. Iowa: Wm. C. Brown Publisher

[22] Curriculum Development Centre 1999. Buku panduan pengajaran dan pembelajaran nilai merentas kurikulum KBSR I KBSM. Kuala Lumpur: Kementerian Pelajaran Malaysia.

[23] Buku Panduan Guru Tingkatan I, II, III, 1988. Pendidikan Jasmani dan Kesihatan. Pusat Perkembangan Kurikulum, Kementerian Pendidikan Malaysia.

[24] Ever Active Schools 2000. Implementing $21^{\text {st }}$ century skills in health and physical education. New Jersey Principals and Supervisors Assocation.

[25] Desma, D., 2001. Strategi pembelajaran Pendidikan Jasmani dan Kesihatan: Satu Kajian Kes. Latihan Ilmiah. UKM, Bangi.

[26] Abdul Aziz, A., 2001. Tahap kematangan, personaliti, kebimbangan dan motivasi dalam pembelajaran aktiviti fizikal di kalangan pelajar sekolah menengah: Satu tinjauan. Latihan Ilmiah. UKM, Bangi.

[27] Halijah I., and Omar A.B., 2008. Tanggapan Kepentingan Mata pelajaran Pendidikan Jasmani dan Kesihatan di sekolah menengah. (Edisi Pertama) Sekudai: Penerbit UTM. 
[28] Haslindah, N., A.G. Diyana Zulaikha, M.N. Mohad Anizu, I. Halijah, Z. Zainal Abidin, R.M. Syahrul, 2011. Persepsi Pelajar dan Guru Sekolah Menengah Terhadap Isu Pemakaian Pakaian Sukan Semasa Kelas Pendidikan Jasmani. Persidangan Kebangsaan Pendidikan Jasmani (NCPE). Anjuran Institut Pendidikan Guru Sultan Mizan pada 27-29 Jun 2011.

[29] Armstrong, N. 1990. New Directions in Physical Education. UK: Human Kinetics Publishers Ltd.

[30] Kassim, M. 2011. Pendidikan Jasmani perlu suntikan baru. Arkib: 27 Jun 2011: Universiti Pertahanan Malaysia. 